\title{
A Noção de Integralidade como Mote para Transformação no Setor Saúde
}

\begin{abstract}
JANE DUTRA SAYD ${ }^{l}$
PINHEIRO, Roseni; MATtOS, Ruben (Org.). Construção da Integralidade: Cotidiano, Saberes e Práticas em Saúde. Rio de Janeiro: IMS/ABRASCO, 2003. 228 p.

Este é o segundo livro do Projeto Integralidade: saberes e práticas no cotidiano das instituições de saúde, lançado no seminário correspondente, em junho de 2003, no IMS/UERJ. Uma coletânea, como o anterior, de textos de diversas procedências, tanto geográficas quanto institucionais e profissionais. O tom atual é, no entanto, diferente, fruto do amadurecimento das discussões e produções do grupo. É possível, portanto, que se esgote mais rápido que o primeiro.

Há maior integração entre os textos, um compartilhamento mais nítido de idéias, uma apresentação mais clara de propósitos; ao mesmo tempo aumenta a abrangência dos temas abordados e a profundidade analítica com que são tratados. Os autores insistem em tratar sua categoria central como um não-conceito ou, como quer Camargo Jr. (capítulo 2), um devir, inalcançável, porém indispensável. Está clara, portanto, a noção de integralidade na saúde como um valor, uma ética para a organização de propostas. Essa ética não se formula de modo definitivo e os autores se recusam, quase em uníssono, a fechar receitas, definir pontos e reinventar chavões.

Conteúdos, propostas teóricas e mesmo termos consagrados na discussão em saúde são utilizados e retomados, mas, curiosamente, todos um pouco fora do lugar original. A noção fugidia de integralidade parece, portanto, uma categoria realmente fértil, já que vai, ao longo dos capítulos, promover deslocamentos de sentido, modificações na avaliação de certos eventos ou ressignificar certos chavões já desgastados por uso abusivo e abstrato no campo da Saúde Coletiva.

A homogeneidade, ou melhor, a consistência interna que percorre os textos não está dada pelas suas recusas e, sim, pelas positividades que emergem do não-fechamento de propostas em palavras de ordem. Quais
\end{abstract}


positividades? Em primeiro lugar, uma primazia da noção de prática. Não de maneira estreita, contraposta a uma teoria, mas a práxis como ação cotidiana e construtora de verdades, mesmo verdades em pesquisa, como querem Madel Luz e Roseni Pinheiro, no primeiro capítulo. As autoras propõem que o cotidiano das instituições de saúde não está aí para ser verificado, cotejado e avaliado contra um modelo racional prévio e abstrato, mas para ser visto como um construtor de práticas, um produto da ação de sujeitos. Da proposta de integralidade surge outra: a de se pensar os serviços com as ferramentas weberianas de ação social.

Camargo Jr., o mais enfático ao negar o estatuto de conceito ao termo integralidade, propõe que ele seja um convite a examinar práticas concretas. Por exemplo, um eixo para se perguntar o que fazem as equipes multidisciplinares, ou como pensar integralidade sem pretender criar uma metafísica em que tudo é ligado à saúde, portanto nada pode ser deixado de lado. A isto o autor contrapõe a idéia de se ter um conhecimento abrangente para que a ação local possa ser efetiva. Novamente a idéia de se examinar ações, de se entender práticas como eventos fabricadores de verdade.

A noção de ação e sujeito permite a Mattos (capítulo 3) reapresentar um termo condenado: o de política de combate a doenças, posto de forma quase jocosa frente à obrigação do comportamento politicamente correto de "política dirigida aos portadores da doença tal". Pois, argumenta candidamente, assim não se faria prevenção, só se atenderia aos já acometidos. E retorna, ressignificada, a noção de que prevenção e cuidado são faces da mesma moeda e só em uma política de combate a doenças, e não de tratamento de doentes, tal dimensão de integralidade pode aparecer. Outrossim, os diagnósticos populacionais e de prevalência de doenças não teriam mais o foco voltado para a supressão dessa prevalência exclusivamente em termos epidemiológicos: trata-se de uma política em que os direitos dos cidadãos e seus desejos recebem uma ampliação de espaço, seu direito a tratar uma morbidade, ou não.

A análise do cotidiano do serviço permite, por outro lado, entendê-lo como uma conversa sem fim, em que a integração tem que se dar com a fala do usuário, do paciente. Todos conversam, é este o trabalho. O que falta é a absorção da fala do paciente como sujeito, integrar esse outro apartado, e aí, sim, há o real acesso ao serviço de saúde de parte do paciente. Outra ressignificação de termos desgastados, usados, enxovalhados e abusados: acesso, escuta, acolhimento. Uma observação interessante sobre as reflexões que médicos de família fazem sobre os limites de suas intervenções no 
cotidiano do paciente levanta a possibilidade de que essa forma de inserção esteja, realmente, permitindo o afloramento da diversidade cultural no espaço da relação médico/paciente, e que o fantasma da medicalização total pode ser conjurado pela escuta real dos desejos do paciente em sua inserção cultural.

De modo novamente rigoroso, a prática é proposta como terreno fecundo de reflexão, ou seja, de experimentação do novo, de sair do pensamento idiossincrásico, auto-referente, da reprodução indefinida de um modelo rígido para a formação profissional. E, assim, as propostas de educação continuada podem estar abertas a redefinições do papel dos profissionais, abertas em rede com estes mesmos profissionais que se transformam à medida que praticam e podem ressignificar, neste caso, sua prática, sua posição, seu papel e sua demanda de conteúdos cognitivos.

Não diríamos, por ser sempre impossível, que o livro é perfeito: há capítulos que contribuem mais do que outros, há alguns em que não se sente essa vibração desaforada que desconstrói chavões e redescobre concretudes. Mas, no conjunto, a própria noção de Sistema Único de Saúde está posta em xeque: uma escuta real dos usuários, uma lida que responde a seus direitos e não a um quadro epidemiológico, uma educação continuada em que o profissional seja agente, não é sistema. Está aberto, sempre sendo refeito, e nesse caso a idéia que passa, de comunicação contínua, pode conformar uma rede, mas nunca um sistema. O livro tem um tom, pode-se dizer, pósmoderno. Seu contínuo recurso ao mundo de experimentação e empirismo são uma desistência sábia, a nosso ver, de definição de modelos fechados. Um empirismo que se põe leve, sem pretensões a enfeixar conceitos rigorosos, pode ser uma ótima maneira de se combater a fragmentação do conhecimento, a especialização e prepotência científicas modernas, tão anacrônicas nesses tempos de hoje.

\section{NOTA}

1 Médica, professora adjunta do Departamento de Planejamento e Administração em Saúde do Instituto de Medicina Social da UERJ. 